\title{
Reliability and Validity of Adapted Ireland Drug Related Knowledge, Attitude and Beliefs Scale among Adolescents in Malaysia
}

\author{
Amin Al Haadi Shafie \\ Asian Centre of Research on Drug Abuse Unit \\ Islamic Science Institute \\ Universiti Sains Islam Malaysia \\ Malaysia. \\ Nurul Ashikin Ahmat Miskam \\ Islamic Science Institute Postgraduate Studies \\ Universiti Sains Islam Malaysia \\ Malaysia
}

\begin{abstract}
Studies on public's awareness level about drug addiction seem to be imperative to bring forth the concerned society that have knowledge on how to deal with drug addicts and open to accept and support drug addicts' recovery process. This research was aimed to study the methodological procedures of instrumentation of scale in which to develop an adapted instrument from Ireland Drug Related- Knowledge, Attitude and Belief Scale (KAB) into Malaysians' context. Face validity of this instrument was undertaken through drug addiction counselling experts' assessment on English and Malay Language (back-to-back- translation) and the content of the items structured. A total of 310 university students were involved answering the questionnaire for reliability test through random sampling technique. Reliability test was recorded high and reliable which was 0.824. This signifies that the adapted Ireland Drug Related-Awareness (Knowledge, Attitude and Beliefs) Scale is highly reliable and applicable to be used among the Malaysian adolescents population.
\end{abstract}

Keywords:Drug-Related Knowledge, Attitude, Beliefs, Adolescents, Reliability and Validity

\section{Introduction}

Drug addiction is considered as a substance use disorder that is illegally depended on drug (Ahmad Bhat, Rahi \& Sidiq, 2015). Keane, Reynolds, Williams \& Wolfe (2006) on the same note add that drug addiction as a maladaptive pattern of substance use that could cause clinical significant impairment shown through repeated substance intake despite the grim withdrawal symptoms if halted as well as the failure of performing the daily tasks for an individual. In Malaysia as in 2017, drug addiction prevalence among adolescents (those aged 13-24) amounts to $23.45 \%$ of the total case which is recorded amounting to 25,922 cases for the whole population (National Anti-Drug Agency, NADA, 2017). This total number of adolescents' involvement in drug addiction is definitely worrying and necessitates immediate efforts either from preventive or interventional perspectives.

According to United Nations Office on Drugs and Crime (2004), a study conducted in India revealing that the level of drug-related knowledge among youths was higher in urban area (84.6\%) compared to the rural area with $61.5 \%$. In Kamaruddin, Abd. Majid \& Abdul Halim (2007), students in higher institution were actually having low knowledge in relation to the effect of drugs after randomly conducting a study upon 3,558 first-year students in higher learning institutions in Malaysia. The contributing factors for adolescents getting involved in illicit drug use are due to peer influence, personal curiosity to trying out drug and pursuing conformity in the social group they are in (Tam \& Foo, 2012).

Talking about the preventive perspective, drug-related awareness of public must be put in concern as one of the ways to increase the advocacy of public on drug addiction. The importance of tracing the level of awareness about drug addiction would help to recognize the risk factors and protective factors of the group of people concerned as so suitable preventive programs and contents can be implemented effectively and fulfil the needs of the group (Chakravarthy, Shah \& Lotfipour, 2013). 
In the year 2000, there was a scale developed to measure the level of drug-related awareness by the researchers from Ireland concerning the constructs of knowledge, attitude and belief about drug addiction (Bryan, Moran, Farrell \& O'Brien, 2000). This instrument measures the aspects that cover perceptions about the extent of the drug problem in society; perceived prevalence of drug use among young people; the perceived dangers associated with drug use; fear and rejection of drug addicted individuals; sympathy/lack of sympathy for drug addicted individuals; attitudes to drug prevention; attitudes to drug treatment; and attitudes to drug control, law enforcement and drug policy (Bryan et.al, 2000). This instrument has been widely used by researchers in drug addiction arena such Kamaruddin et.al (2007) in his research on KAB among university's students in Malaysia as well as Balsam et.al (2016) in their research on this matter among Pahang Matriculation Students in Malaysia.

Therefore, this paper is written to present the procedural process of this Ireland KAB scale in term of its reliability and validity value that forms the adapted version specifically in Malaysian context and language. Reliability value and instrument validity are to be presented to ensure the instrument is applicable to be used among Malaysian population.

\section{Methodology and Findings}

\section{Sample and Sampling Technique}

Sample is defined as a portion of a population or universe (Tailor, 2005). According to Collis \& Hussey (2003), it is necessary to clearly define the target population of a study and they define population as a set of people or collection of items under a few steps of considerations. Determining the right sample size in a reliability test is very important. If the sample size is too small, not much information can be obtained from the test in order to draw meaningful conclusions; on the other hand, if it is too large, the information obtained through the tests will be beyond that needed, thus time and money are wasted (Gerokostopoulos, Guo \& Pohl, 2015). Therefore, 310 university students were administered with this scale to evaluate its reliability value. Moreover, sampling technique used in this study was purposeful technique. The purposive sampling technique or better known as judgment sampling is the deliberate criteria of a participant due to the qualities the participants have (Etikan, Sulaiman \& Rukayya, 2016). Due to the context of this research being focused on the awareness among adolescents, the sample of this study was focused on university students in Negeri Sembilan, Malaysia. The students aged from 20-25 years old coming from two different faculties in the same university.

\section{Items}

This study adapted the Ireland Drug Related Knowledge, Attitude and Beliefs Scale (KAB) by Bryan et.al(2000). The aspects changed were in term of language (which was from English Language to Malay Language) and the omitted structure of the origin instrument in question one. The adapted version still remains the structures of this instrument which consists of 39 questions with 3 parts; (Part A: Demographic information of the respondents), (Part B: DrugRelated Knowledge) and (Part C: Drug-Related Attitude and Belief). Table 1.0 and 2.0 below outline the items of the Adapted Ireland Drug Related-Awareness (Knowledge, Attitude and Beliefs) Scale.

\section{Table 1.0 Item with 5-Likert Scale}

\begin{tabular}{|l|l|}
\hline & ITEMS \\
\hline 1 & $\begin{array}{l}\text { All illegal drugs are equally harmful to your health. } \\
\text { Semuajenisdadahterlarangadalahberbahayakepadakesihatananda. }\end{array}$ \\
\hline 2 & $\begin{array}{l}\text { Our society is too tolerant towards drug users. } \\
\text { Masyarakatkitaterlalubertolakansurkepadapenagihdadah. }\end{array}$ \\
\hline 3 & $\begin{array}{l}\text { If you try drugs even once, you are hooked. } \\
\text { Jikaandamencubadadahsekali, sudahpastiandaakanterusbergantungdengannya. }\end{array}$ \\
\hline 4 & $\begin{array}{l}\text { I would see drug addicts more as criminals than victims. } \\
\text { Sayamelihatpenagihdadahsebagaiseorangpenjenayah. }\end{array}$ \\
\hline 5 & $\begin{array}{l}\text { Most young people today try out cannabis. } \\
\text { Kebanyakangolonganbeliahariinicubamenghisap ganja. }\end{array}$ \\
\hline 6 & $\begin{array}{l}\text { Alcohol abuse causes more problems in society than drug abuse. } \\
\text { Penyalahgunaanalkoholmenyebabkanlebihbanyakmasalahkepadamasyarakatberbandingpenyalahgunaandadah. }\end{array}$ \\
\hline 7 & $\begin{array}{l}\text { Treatment should only be given to drug addicts who intend to give up drugs for good. } \\
\text { Rawatanhanyadiberikankepadapenagihdadah yang berhasratuntukberubah. }\end{array}$ \\
\hline 8 & $\begin{array}{l}\text { I would tend to avoid someone who is a drug addict. } \\
\text { Sayaberusahauntukmengelakseseorang yang ketagihdengandadah. }\end{array}$ \\
\hline 9 & $\begin{array}{l}\text { I would be nervous of someone who uses illegal drugs. } \\
\text { Sayaakangementarapabilaadaseseorangterlibatdalampenyalahgunaandadah. }\end{array}$ \\
\hline
\end{tabular}


10 Money spent on the prevention of drug use, is money well spent.

Wang yang dibelanjakandenganbaikadalahwang yang digunakanuntukpencegahanpenyalahgunaandadah

The use of cannabis should not be against the law.

11 Penggunaan ganja tidaksepatutnyamenyalahiundang-undang.

Drug addicts are not given a fair chance to get along in society.

12 Penagihdadahtidakdiberipeluang yang saksamauntukbergauldenganmasyarakat.

Occasional use of cannabis is not really dangerous.

13 Penggunaan ganja sekali-sekalatidaklahbegitubahaya.

People who end up with a drugs problem have only themselves to blame.

14 Orang yang patutdipersalahkandalammasalahdadahadalahpenagihdadahitusendiri.

Most young people today try out ecstasy.

15 Kebanyakangolonganbelialebihmendorongterhadapketagihanecstacy.

Drugs are not really a problem to us here in this neighborhood.

16 Dadahsebenarnyatidakbegitumemberimasalahterhadapjirantetangga di sini.

Treatment should be available to all drug addicts, according to their needs.

17 Rawatan yang disediakankepadapenagihsewajarnyamengikutkeperluanpenagihtersebut.

Drug addicts really scare me.

18 Penagihdadahbenar-benarmenakutkansaya.

Tougher sentence for drug misusers is the answer to the drugs problem.

19 Hukuman yang lebihberatkepadapenggunadadahadalahcarapenyelesaiankepadamasalahberkaitandadah.

Most people are concerned about the drug problem in Malaysia.

20 Kebanyakanmasyarakat Malaysia bimbangterhadapmasalahpenyalahgunaandadah.

Occasional use of ecstasy is not really dangerous.

21 Penggunaanecstacysekali-sekalatidaklahberbahaya.

Many drug addicts exaggerate their troubles to get sympathy.

22 Kebanyakanpenagihdadahmembesar-besarkanmasalahuntukmendapatkansimpati.

It is normal that young people will try drugs at least once.

23 Adalahsesuatu yang normal jikaanakmudabeliamencubadadahsekurang-kurangnyasekali.

The drug problem in Malaysia is out of control.

24 Masalahdadah di Malaysia adalahtidakterkawal.

Medically prescribed heroin substitutes such as methadone should be available to drug addicts.

25 Dadah-dadah yang didaftarkanseperti Methadone seharusnyamudahdiaksesolehkelompokpenagihdadah.

Almost all drug addicts are dangerous.

26 Kebanyakanpenagihdadahadalahberbahaya.

Drugs education in school should start at primary level.

27 Pendidikanpencegahandadahsewajarnyabermula di sekolahrendah.

Drug related crime is a major problem in Malaysia today.

28 Jenayahberkaitandadahadalahmasalahutama di Malaysia padamasakini.

Occasional use of heroin is not really dangerous.

29 Penggunaan heroin sekali-sekalaadalahtidakbegituberbahaya.

Reports about the extent of drug usage amongst young people are exaggerated by the media.

30 Pihak media seringmembesar-besarkanisupenyalahgunaandadahdalamkalanganbelia.

Society should provide syringes and needles free of charge to drug addicts to avoid the spread of HIV.

Masyarakatseharusnyamenyediakanjarumsuntikan

31 bersihsecarapercumakepadapenagihdadahuntukmengelakkanpenyebaranpenyakitberjangkitseperti HIV.

Drug addicts charged with petty offences should be given a choice between treatment and prison service.

32 Penagihdadah yang dihukumataskesalahankecilharusdiberipilihanantararawatnataupenjara.

It would bother me to live near a person who is a drug addict.

33 Hidupsayaakantergangguapabilaberhamirandenganseorangpenagihdadah.

Regular use of cannabis is just as dangerous to your health as regular use of heroin.

34 Penggunaan ganja secaraberterusanadalahberbahayakepadakesihatanseseorangsamasepertikesan yang samadengan heroin.

The availability of illegal drugs poses a great threat to young people nowadays.

35 Dadahterlarang yang senangdidapatimenyebabkanancaman yang sangathebatbagigenerasibeliahariini 
Table 2.0 Items with 2-Likert Scale (Yes/No)

\begin{tabular}{|l|l|}
\hline & ITEMS \\
\hline 36 & $\begin{array}{l}\text { I personally know someone who smokes cannabis. } \\
\text { Sayamengenaliseseorang yang menghisap ganja. }\end{array}$ \\
\hline 37 & $\begin{array}{l}\text { Have you ever taken cannabis? } \\
\text { Pernahkahandamengambil ganja. }\end{array}$ \\
\hline 38 & $\begin{array}{l}\text { I personally know someone who has/had a drug problem. } \\
\text { Sayamengenaliseseorang yang mempunyaimasalahdadah. }\end{array}$ \\
\hline 39 & $\begin{array}{l}\text { I am aware about the effect of drug misuse. } \\
\text { Sayasedarakankesanterhadappenyalahgunaadadah. }\end{array}$ \\
\hline
\end{tabular}

\section{Instrument Reliability}

Alpha Cronbach's Value

Table 3.0 Reliability Value for Adapted Ireland Drug Related-Awareness (Knowledge, Attitude and Beliefs) Scale

\begin{tabular}{lll}
\hline Cronbach's Alpha & $\begin{array}{l}\text { Cronbach's Alpha } \\
\text { Standardized Items }\end{array}$ & Based on N of Items \\
\hline .824 & .810 & 39 \\
\hline
\end{tabular}

(Source from SPPS Version 20.0)

Table 3.0 shows the reliability value of this 40 items-adapted-instrument with the value of Cronbach's Alpha, 0.824 while value 0.810 is recorded based on Cronbach's Alpha based on standardized items.

Split-Half Reliability Test

Table 4.0 The Split- Half Reliability Test for Adapted Ireland Drug Related-Awareness (Knowledge, Behaviours and Beliefs) Scale among Adolescentss.

\begin{tabular}{|c|c|c|c|}
\hline \multicolumn{4}{|c|}{ Reliability Statistics } \\
\hline \multirow{5}{*}{ Cronbach's Alpha } & \multirow[t]{2}{*}{ Part 1} & Value & .760 \\
\hline & & $\mathrm{N}$ of Items & $20^{\mathrm{a}}$ \\
\hline & \multirow{2}{*}{ Part 2} & Value & .759 \\
\hline & & $\mathrm{N}$ of Items & $19^{\mathrm{b}}$ \\
\hline & \multicolumn{2}{|c|}{ Total $\mathrm{N}$ of Items } & 39 \\
\hline \multicolumn{3}{|c|}{ Correlation Between Forms } & .791 \\
\hline \multirow{2}{*}{$\begin{array}{l}\text { Spearman-Brown } \\
\text { Coefficient }\end{array}$} & \multicolumn{2}{|c|}{ Equal Length } & .781 \\
\hline & \multicolumn{2}{|c|}{ Unequal Length } & .781 \\
\hline \multicolumn{3}{|c|}{ Guttman Split-Half Coefficient } & .758 \\
\hline
\end{tabular}

(Source from SPPS Version 20.0)

Table 4.0 shows the value of split-half value for this instrument. The Cronbach's Alpha for the first 20 items (Part1) is 0.760 whereas the last 19 items is 0.759 . The correlation between the two parts recorded the Cronbach Alpha for 0.791. This depicts the high value of reliability for this instrument and valid to be used. Cronbach's Alpha if Item Deleted 
Table 5.0 The value of mean, standard deviation and Cronbach Alpha if deleted

\begin{tabular}{|c|c|c|c|c|}
\hline \multicolumn{5}{|c|}{ Item Statistics } \\
\hline ITEMS & Mean & $\begin{array}{l}\text { Std. } \\
\text { Deviation }\end{array}$ & $\mathbf{N}$ & $\begin{array}{l}\text { Cronbach's Alpha if } \\
\text { Item Deleted }\end{array}$ \\
\hline Item 4 & 6.25 & 1.450 & 310 & 0.823 \\
\hline Item 5 & 4.25 & 1.799 & 310 & 0.824 \\
\hline Item 6 & 5.54 & 1.747 & 310 & 0.825 \\
\hline Item 7 & 4.85 & 1.688 & 310 & 0.819 \\
\hline Item 8 & 4.96 & 1.437 & 310 & 0.821 \\
\hline Item 9 & 5.74 & 1.468 & 310 & 0.822 \\
\hline Item 10 & 3.84 & 1.983 & 310 & 0.824 \\
\hline Item 11 & 5.52 & 1.596 & 310 & 0.819 \\
\hline Item 12 & 5.49 & 1.515 & 310 & 0.820 \\
\hline Item 13 & 5.03 & 1.733 & 310 & 0.823 \\
\hline Item 14 & 2.72 & 2.067 & 310 & 0.828 \\
\hline Item 15 & 4.12 & 1.775 & 310 & 0.824 \\
\hline Item 16 & 2.68 & 1.869 & 310 & 0.829 \\
\hline Item 17 & 4.56 & 1.803 & 310 & 0.820 \\
\hline Item 18 & 4.87 & 1.475 & 310 & 0.821 \\
\hline Item 19 & 2.10 & 1.569 & 310 & 0.827 \\
\hline Item 20 & 5.23 & 1.540 & 310 & 0.824 \\
\hline Item 21 & 5.58 & 1.513 & 310 & 0.819 \\
\hline Item 22 & 5.16 & 1.640 & 310 & 0.821 \\
\hline Item 23 & 2.55 & 1.704 & 310 & 0.828 \\
\hline Item 24 & 5.98 & 1.295 & 310 & 0.822 \\
\hline Item 25 & 4.25 & 1.652 & 310 & 0.820 \\
\hline Item 26 & 2.19 & 1.788 & 310 & 0.826 \\
\hline Item 27 & 5.12 & 1.571 & 310 & 0.823 \\
\hline Item 28 & 3.63 & 1.638 & 310 & 0.825 \\
\hline Item 29 & 5.30 & 1.685 & 310 & 0.819 \\
\hline Item 30 & 6.43 & 1.106 & 310 & 0.822 \\
\hline Item 31 & 5.84 & 1.408 & 310 & 0.821 \\
\hline Item 32 & 2.25 & 1.600 & 310 & 0.830 \\
\hline Item 33 & 4.16 & 1.816 & 310 & 0.825 \\
\hline Item 34 & 3.71 & 2.271 & 310 & 0.827 \\
\hline Item 35 & 4.77 & 1.760 & 310 & 0.827 \\
\hline Item 36 & 6.16 & 1.246 & 310 & 0.818 \\
\hline Item 37 & 6.27 & 1.229 & 310 & 0.819 \\
\hline Item 38 & 1.64 & .480 & 310 & 0.820 \\
\hline Item 39 & 1.99 & .113 & 310 & 0.829 \\
\hline
\end{tabular}

(Source from SPPS Version 20.0)

Based on Table 5.0 above, the values of the reliability scale of this adapted instrument are all in the range of constantly stable if one of the items is deleted. This instrument will be highly reliable at Cronbach Alpha 0.83 when Item 32 is deleted.

\section{Instrument Validity}

\section{Back-to-Back Translation Process}

Due to the cultural background differences, the adaptation of cross-cultural was employed in translating the psychological testing particularly in bringing out the very meaning of each item in the scale available in this instrument. Therefore, the back translation technique was made possible in this study. First, the actual instrument was translated by the two appointed experts in English Language and Addiction Counselling from English to Malay version. The need of undergoing the translation from English to Malay was because it is the respondents' native language, thus, the depth and breadth of respondents' understanding to each item would possibly being captured. However, as to ensuring the semantically accuracy of the translation that has been made, the back translation was 
undergone from English to Malay version to put both versions in accordance with the meaning of each item intended in the original counterpart.

This has been done in tandem with the guidelines of instrumentation useful for writing new items and modifying existing items propounded by (Brislin, Lonner \& Thorndike, 1973) saying that it is to assure that translators should have a clear understanding of the original language item, possess a high probability of finding a readily available target language equivalent as so they are not necessary to employ convoluted terms and capable of producing the readily understandable target language item by the eventual set of respondents who are involved in data-gathering stage of research. Chiefly, back translation has been suggested as a quality-control check because the process takes a few stages to be done. Generally, back translation is functioning to detect errors in translation and it involves the extensive checking, pretesting of the translation and also debriefing, crucial to make sure a reliable and accurate translation (Douglas \& Craig, 2007).

The translator that fully proficient in both languages is needed in back translation to ensure that it has the same understanding of the subject domain measured. And to gain the best translation, the translator usually will avoid literal translation which is word by word being translated alone and combine it at the end as a sentence. It is crucial for the translator to use such a different word but carry the same meaning across languages (Sireci, Yang, Harter \&Ehrlic, 2006).

On the same note, Pym (2010) connotes that back-translation is when a translated document is translated (back) into the original language. The idea is that the author can then verify whether the translation encompasses all aspects of the original. According to Behling\& Law (2000), back translation is considerably a well-renowned method in preserving the very meaning of the original version. The researchers of this study who are all learned in the area of counselling have also established the face validity technique in this research. After preparing this instrument in both versions, the face validity was imposed. Two counsellors are approached to undergo the face validity upon the instrument that is in Malay version to obtain their insights on the subject matter assigned. Face Validity

Researchers also underwent face validity process upon the instrument. The researchers appointed 2 experts in drug abuse counselling to give assessment on the content and context of the scale particularly in line with Malaysians' level of awareness in drug. Patton (1997) defines face validity as the extent to which an instrument looks as if it measures what it is intended to measure. If one can look at an instrument and understand what is being measured, it has face validity. Face validity is indeed a complex and multidimensional construct that are helpful for measuring how test items are appeared to respondents and others (Suzanne, Donna, Kristopher \&Arheart, 1992). As opined by Brickman, Rabinowits, Karuza, Coates, Cohn \& Kidder (1982), face validity is well- known as the simplest assessment of validity technique because it does not involve any statistical or numerical technicality in implementing it whereas Engel \& Schutt (2013) affirm that face validity is believed to be very casual, soft and often being perceived as passive measure of validity. Another celebrated view on face validity propounded by Sangoseni, Hellman \& Hill (2013) is that face validity seeks the experts to inspect the items provided in questionnaire and endorse the test as valid in tandem with the concept involved that is being measured just on the face of it, thus experts are expected to measure whether each item matches any conceptual domain of the concept.

\section{Discussion}

\section{Cronbach Alpha Value}

Reliability of a research instrument can be defined as the extent to which repeat measurements with the instrument under the same conditions produce the same results (Bryn et al. 2000). One of the ways to evaluate the reliability of an instrument is through Cronbach Alpha value. This adapted version of Ireland Drug Related-Awareness (Knowledge, Attitude and Beliefs) Scale is 0.824 meaning that it has high reliability value. This is in accordance with the opinion given by Piaw in Amin Al Haadiet al. (2017) mentioned that correlation values ranging from 0.75 to 0.95 indicates the satisfactory reliability.

\section{Split Half Reliability Test}

Split- Half reliability technique was used to assess the validity consistency of the scale.According to Nugent (2013), split-half reliability correlates responses from one half of a test with the other half. In Amin, Zuria, Salleh, Amla, Kamaruzaman \& Mizan Adiliah (2011), Piaw (2006) noted that split-half technique is one way to measure the reliability of a quantitative research. This technique is done by splitting the items of the scale into two groups and computing and analysing the correlation values. In this study, the Cronbach's Alpha for the first 20 items (Part1) is 0.760 whereas the last 19 items is 0.759 . The correlation between the two parts recorded the Cronbach Alpha, 0.791 . This depicts the high value of reliability for this instrument and valid to be used. The reliability is considered high if the items in both groups are highly correlated. 
Rudner and Schafer (2001) also mention that split-half reliability coefficient is obtained by dividing the test into half, correlating the score by each half and correcting for length. The split is based on odd versus even items numbers, randomly selected items, or manually balancing content and difficulty. The advantage of this approach is that it only needs a single test administration. Piaw (2006) also mentioned that correlation values ranging from 0.75 to 0.95 indicate satisfactory reliability.

\section{Cronbach Alpha's Value Items if Deleted}

This analysis touches on the value of Cronbach's Alpha that shows the internal consistency of an instrument. In this study, the stable internal consistency values have been recorded through this analysis in which the values of Cronbach's Alpha are ranged from 0.719 to 0.830 . The highest value as at 0.830 Cronbach Alpha value, this instrument is possible to reach when item 32 is deleted.

In this sense, this instrument has less need to be improved in term of its reliability value. According to Raykov (2008), if we are using an accepted scale obtained from a published source, we do not need to worry about improving reliability. We should use the whole scale, even if it has problems, because if we start changing the scale, we will be unable to compare our results to the results of others who have used the scale. This shows that the act of improving reliability value is only applicable for self-developed instrument and not that of adapted one to promote comparative study between researches that utilizing the same instrument.

\section{Conclusion}

In conclusion, the Ireland Drug Related-Awareness (Knowledge, Attitude and Beliefs) Scale by Bryn et.al (2000) was applicable to be used in Malaysia because it has attained the high value of reliability and internal consistency through simple reliability test and split half test respectively. The face validity conducted enhanced the validity of the scale that really measures the level of awareness of the adolescents in drug abuse with respect to knowledge, attitude and beliefs.

\section{References}

Amin, A.H.S., M. Zuria, A. Salleh, S. Amla, J.Kamaruzaman and Mizan, A.(2011)Reliability andvalidity of peer aggression coping self-efficacy scale.World Applied Sciences Journal. Vol 34, 1685-1691.

Balsam, M.N.Z., Maher, D.F., Hasanain, F.G., Mohamed A. A., Maged, E. \&Mohamaed, F.B.(2016). Knowledge, attitudes and beliefs related to drug among Pahang Matriculation Students in Malaysia. International Jornal of Public Health Research.Vol 6(2).750-760.

Behling, O. \&Law,K.S (2000). Translatingquestionnaires and other research instrument:Problem and solutions. Thousand Oaks: SagePublication.

Bhat, B.A., Rahi, S. \&Sidiq, M.M. (2015).Awareness of drug addiction among college students of Kashmir Valley.International Journal of Medical Sciences \& Pharmaceutical Research. Vol. 1(1), 01-14.

Brickman, P., Rabinowits, C.V., Karuza, J.J., Coates, D., Cohn, E \& Kidder, L.(1982). Models of helping and coping.American Psychologist. Vol. 37, 368-384.

Brislin, W., Lonner, J. \& Thorndike, M. (1975).Cross-cultural research methods. New York: John Wiley and Sons

Bryan, A., Moran, R., Farrell, E. \& O’Brien, M. (2000).Drug-related knowledge, attitudes and beliefs in Ireland: Report of a nation-wide survey. Dublin: Drug Misuse Research Division The Health Research Board.

Chakravarthy, B., Shah, S. \&Lotfipour, S. (2013). Adolescent drug abuse: Awareness \& prevention. Indian Journal of Medical Research.Vol 137 (6).1021-1023.

Collis, J.\& Hussey, R. (2003), Business research: A practical guide for undergraduate and postgraduate students. Hampshire: Palgrave Macmillan Inc.

Douglas, S.P. \& Craig, C.S. (2007). Collaborative and iterative translation: An alternative approach to back translation. Journal of International Marketing. Vol. 15 (1), 30-43.

Engel, R.J. \&Schutt, R.K. (2015).Measurement in the practice of research in social work, $3^{\text {rd }}$ ed. Carlifornia: Sage Publication.

Etikan, I., Sulaiman, A.M. \&Ruqkayya, S.A.Comparison of convenience sampling and purposive sampling.American Journal of Theoretical and Applied Statistics. Vol 8 (1), 1-4.

Gerokostopoulos, A. Guo, H. \& Pohl, E. (2015).Determining the right sample size for your test: Theory and application. . Greenland: ReliaSoft Corporation.

Kamarudin, H., Abd Majid, M., Abdull Halim, A. (2007). A study on drug abuse among new students of institutions of higher learning. Malaysian Anti-Drugs Journal. Vol 2, 1-12. 
Keane, R., Reynolds, S.R., Williams, J. \& Wolfe, E. (2006).Understanding substances and Substance use: A handbook for teachers. South Western: Addiction Services and Health Promotion Department South Western Area Health Board.

National Anti-Drug Agensi Malaysia (2017).Malaysia Drug Information 2017.Bangi: Ministry of Internal Affairs.

Nugent, M., 2013.Split-half reliability.RetrievedfromPsychology Dictionary: Nugent (2013), split-half reliability. Available online https://psychologydictionary.org/split-half-reliability/

Patton, M. (1997).Utilization-focused evaluation. Thousand Oaks: Sage Publication.

Piaw, C.Y.,(2006). Kaedahdanstatistikpenyelidikan.Kuala Lumpur: McGraw Hill Education.

Pym, A. (2010). Exploring translation theories.New York: Routledge.

Raykov, T. (2008). Alpha if item deleted: A note on loss of criterion validity in scale development if maximizing coefficient alpha. British Journal of Mathematical and Statistical Psychology. Vol 61, 1024-1030.

Rudner, L.M. \&Schafer, W.D.( 2001). Reliability.Retrieved from ERIC Clearinghouse on Assessment and Evaluation. Available onlinehttp://www.ericdigests.org/2002-2/reliability.htm (April, 28,2019)

Sangoseni, O., Hellman, M. \& Hill, C. (2013).Development and validation of a questionnaire toaccess the effect of online learning on behaviours.Journal of Allied Health Science Practice. Vol 11, 1-12.

Sireci, S.G.,Yongwei, Y, Harter, J. \&Ehrlich, A.J.(2006)Evaluating guidelines for test adaptations:A methodological analysis of translation quality.Journal of Cross-Cultural Psychology. Vol 37, 557-567.

Suzanne, D., Donna, T., Kristopher, K.H. \& L. Artheart.(2016).Face validity. Western Journal of Nursing Research. Vol. 4, 109-112.

Tailor, G. R (2005). Integrating quantitative and qualitative methods in research (Ed.). Maryland: University Press of America Inc.

Tam C. \& Foo Y. (2012). Contributory factors of drug abuse and the accessibility of drugs. 1st ed. [ebook]. Available at: http://contributory-factors-of-drug-abuse-and-the-accessibility-of-drugs.pdf). (May, 12, 2019)

United Nations Office on Drugs and Crime VIENNA. School-Based Education for Drug Abuse Prevention. (EBook) (2004). Available at: https://www.unodc.org/pdf/youthnet/handbook_school_english.pdf. (May, 9, 2019) 